\title{
Gambaran Tingkat Pengetahuan Wanita Usia Subur Tentang HIV/AIDS di Wilayah Kerja Puskesmas Gurah Kabupaten Kediri
}

\author{
Yunias Dwi Ningrum ${ }^{1}$, Ratna Frenty Nurkhalim² ${ }^{2}$ Oktovina Rizky I. ${ }^{3}$ \\ ${ }^{123}$ Institut IImu Kesehatan Bhakti Wiyata Kediri \\ 'yuniasdwiningrum@gmail.com
}

\begin{abstract}
HIV / AIDS is an infectious disease caused by infection with the Human Immunodeficiency Virus (HIV) which attacks the immune system. (RI Ministry of Health, 2017). The high case of HIV / AIDS in women is feared to have an impact on the increase in cases of HIV / AIDS in children who get from perinatal transmission or transmission of infections that occur during pregnancy or childbirth. Another contributing factor is the lack of knowledge and awareness about HIV / AIDS that has threatened ordinary people including women of childbearing age. This study aims to determine the level of knowledge of women of childbearing age about HIV / AIDS in the Gurah Health Center area of Kediri Regency. The method used was cross-sectional by distributing questionnaires to a group of women of childbearing age with a total sample of 98 respondents. With variables including the characteristics of respondents and knowledge of HIV / AIDS. Based on the research results obtained for the most age at the end of adulthood (35.7\%), the most education was high school / vocational school (62.2\%), IRT work (65.3\%), electronic media information sources (41.8\%). While knowledge of HIV / AIDS was sufficient as much as 43.9\%, knowledge about transmission is low (49.9\%), knowledge of prevention about limiting sexual relations (70.4\%), condom use (55.1\%), knowledge of signs and symptoms of people appear healthy (73.5\%), knowledge of characteristics affected by HIV / AIDS (59.2\%), knowledge of prevention of HIV / AIDS testing (54.1\%), and place of testing services (53.1\%). The conclusion that can be taken was the level of knowledge of women of childbearing age about HIV / AIDS was in the sufficient category and was expected to be further improved so that it becomes a high level by conducting counseling by health workers in the Puskesmas and other agencies
\end{abstract}

Keywords: HIV/AIDS, knowledge, women of childbearing age

\begin{abstract}
Abstrak: HIV/AIDS merupakan penyakit menular yang disebabkan oleh infeksi Human Immunodeficiency Virus (HIV) yang menyerang sistem kekebalan tubuh. (Kemenkes RI, 2017). Tingginya kasus HIV/AIDS pada perempuan dikhawatirkan akan ikut berdampak pada peningkatan kasus HIV/AIDS pada anak-anak yang didapat dari penularan melalui perinatal atau penularan infeksi yang terjadi pada saat kehamilan atau persalinan. Faktor penyebab lainnya adalah kurangnya pengetahuan dan kesadaran tentang HIV/AIDS yang telah mengancam kalangan orang biasa termasuk wanita usia subur. Penelitian ini bertujuan untuk mengetahui tingkat pengetahuan wanita usia subur tentang HIV/AIDS di wilayah Puskesmas Gurah Kabupaten Kediri. Metode yang digunakan adalah cross-sectional dengan menyebarkan kuesioner ke kelompok wanita usia subur dengan jumlah sampel sebanyak 98 responden. Dengan variabel meliputi karakteristik responden dan pengetahuan HIV/AIDS. Berdasarkan penelitian diperoleh hasil untuk usia terbanyak pada dewasa akhir (35.7\%), pendidikan terbanyak yaitu SMA/SMK (62.2\%), pekerjaan IRT (65.3\%), sumber informasi media elektronik ( 41.8\%). Sedangkan pengetahuan HIV/AIDS yaitu cukup sebanyak 43.9\%, pengetahuan mengenai
\end{abstract}


penularan yaitu rendah (49.9\%), pengetahuan pencegahan tentang membatasi hubungan seksual (70.4\%), pemakaian kondom (55.1\%), pengetahuan tanda dan gejala orang tampak sehat (73.5\%), pengetahuan ciri terkena HIV/AIDS (59.2\%), pengetahuan penanggulangan adanya tes HIV/AIDS (54.1\%), dan tempat pelayanan tes $(53.1 \%)$. Simpulan yang dapat diambil adalah tingkat pengetahuan wanita usia subur tentang HIV/AIDS berada pada kategori cukup dan diharapkan dapat lebih ditingkatkan sehingga menjadi tingkatan yang tinggi dengan dilakukan penyuluhan oleh tenaga kesehatan yang ada di Puskesmas maupun instansi lainnya.

Kata kunci: HIV/AIDS, pengetahuan, wanita usia subur

\section{Pendahuluan}

Pertarungan melawan HIV/AIDS masih terus berlangsung hingga sekarang. Penyakit menular ini menyerang laki-laki maupun perempuan. Penyakit ini disebabkan oleh infeksi Human Immunodeficiency Virus (HIV). Infeksi tersebut menyebabkan penderita mengalami penurunan ketahanan tubuh sehingga sangat mudah untuk terinfeksi berbagai macam penyakit lain. ${ }^{1}$

Data WHO (World Health Organization) menunjukkan bahwa HIV/AIDS telah menginfeksi hampir 78 juta orang dan menyebabkan sekitar 39 juta orang telah meninggal sejak awal epidemi tahun 1981. Pada akhir 2013, WHO juga mencatat 35 juta orang hidup dengan HIV. Dari jumlah tersebut, 0,8\% nya ialah kelompok umur 15-49 tahun. ${ }^{2}$ Pada tahun 2017, orang dengan penderita HIV terbanyak berada pada wilayah Afrika dengan jumlah 25,7 juta jiwa penderita HIV sedangkan Asia berada pada urutan kedua setelah Afrika dengan jumlah penderita HIV sebanyak 3,5 juta jiwa. ${ }^{3}$

Indonesia ialah salah satu negara di Asia yang memiliki jumlah kasus baru HIV cukup tinggi sebanyak 49.000 jiwa setelah India yang memiliki jumlah kasus baru HIV sebanyak 88.000 jiwa. $^{3}$ Jumlah kasus baru HIV/AIDS yang dilaporkan dari tahun ke tahun cenderung menunjukkan peningkatan. Pada tahun 2015, jumlah kasus yang ditemukan sebanyak 30.935. Pada tahun berikutnya, jumlahnya meningkat sebanyak 41.250, dan pada tahun 2017 meningkat lagi sebanyak 48.300 kasus. $^{4}$

${ }^{1}$ KEMENKES, Profil Kesehatan Indonesia Tahun 2016, 2016.

2World Health Organization, Global Update on HIV Treatment 2013: Results, Impact and Opportunities, 2013.

${ }^{3}$ World Health Organization, Consolidated Guideline on Sexual and Reproductive Health and Rights of Women Living with HIV, 2017.

${ }^{4}$ Kemenkes Direktorat Jenderal Penanggulangan dan Pencegahan Penyakit serta Penyehatan Lingkungan, Laporan Perkembangan HIV-AIDS \& Penyakit Infeksi Menular Seksual (PIMS) Triwulan I Tahun 2017., 2017. 
Peningkatan jumlah kasus juga ditemukan di Provinsi Jawa Timur. Provinsi Jawa Timur sempat menduduki peringkat pertama HIV di Indonesia pada tahun 2017 dengan jumlah kasus baru HIV sebanyak 8.204 kasus. ${ }^{5}$ Sedangkan Kabupaten Kediri pada kurun waktu 5 tahun terakhir, juga menunjukkan peningkatan penderita HIV/AIDS terus menerus.

Peningkatan ini dikarenakan adanya upaya penemuan diagnosis yang makin meluas, dengan adanya penambahan jumlah layanan tes HIV yang ada di Kabupaten Kediri. ${ }^{5}$

Ibu Rumah Tangga yang termasuk dalam kelompok Wanita Usia Subur merupakan salah satu kelompok berisiko tinggi terkena HIV/AIDS. Pada tahun 2016 Ibu Rumah Tangga berada pada urutan ketiga, ${ }^{6}$ sedangkan pada tahun 2017, Ibu Rumah Tangga berada pada urutan kedua berdasarkan profesi kasus HIV. ${ }^{7}$ Di Kabupaten Kediri, Ibu Rumah Tangga merupakan kelompok berisiko tertinggi kedua dan mengalami peningkatan dari tahun 2016 sebanyak 195 kasus (Laporan Surveilans HIV/AIDS, 2016) dan pada tahun 2017 sebanyak 234 kasus. $^{8}$

Kasus HIV/AIDS yang tinggi pada perempuan dapat mengakibatkan peningkatan pada kasus HIV/AIDS pada anak-anak. Penularannya yaitu melalui perinatal atau penularan infeksi yang terjadi pada saat kehamilan atau persalinan. Perempuan dengan HIV/AIDS mengalami berbagai permasalahan secara fisik, psikososial, emosional maupun spiritual. Secara fisik, perempuan dengan HIV/AIDS mengalami penurunan daya tahan tubuh sehingga rentan terhadap berbagai penyakit infeksi. Perempuan dengan HIV/AIDS dapat dikucilkan oleh teman, keluarga maupun masyarakat secara sosial. ${ }^{9}$

Selain disebabkan oleh penularan perinatal, HIV juga dapat disebabkan oleh faktor kurangnya pengetahuan dan kesadaran tentang HIV/AIDS. Khalayak perlu tahu bahwa penyebaran virus ini tidak hanya mengancam kelompok dengan perilaku seks yang tidak aman, tetapi juga telah mengancam kalangan Ibu Rumah Tangga (IRT) yang suaminya telah terjangkit virus tersebut. Hasil penelitian menunjukkan bahwa IRT bisa saja terjangkit HIV meskipun dia Nampak seperti IRT normal. ${ }^{10}$

Berdasarkan data awal di Kabupaten Kediri pada tahun 2018 ditemukan kasus baru HIV tertinggi terdapat di wilayah Puskesmas Gurah dengan perolehan angka yaitu 13 kasus baru, 7 diantaranya merupakan perempuan dan seluruhnya merupakan

${ }^{5}$ KEMENTERIAN KESEHATAN REPUBLIK INDONESIA, Profil Kesehatan Indonesia Tahun 2017 (JAKARTA, 2017).

${ }^{6}$ KEMENKES, Profil Kesehatan Indonesia Tahun 2016.

${ }^{7}$ KEMENTERIAN KESEHATAN REPUBLIK INDONESIA, “Profile Kesehatan Indonesia Tahun 2017," Ministry of Health Indonesia.

8KEMENTERIAN KESEHATAN REPUBLIK INDONESIA, Profil Kesehatan Indonesia Tahun 2017.

${ }^{9}$ Nur Azizah Indriastuti, "Faktor-Faktor Yang Mempengaruhi Pencapaian Peran Sebagai Ibu Pada Perempuan Dengan HIV/AIDS Di Yogyakarta," Mutiara Medika: Jurnal Kedokteran dan Kesehatan 15, no. 1 (2015): 75-83.

${ }^{10}$ Ibid. 
perempuan pada usia subur yaitu usia 20-45 tahun. Dari data tersebut, maka perlu dilakukan penelitian mengenai Gambaran Tingkatan Pengetahuan Wanita Usia Subur mengenai HIV/AIDS di Wilayah Kerja Puskesmas Gurah Kabupaten Kediri pada tahun 2019.

\section{Metode Penelitian}

Penelitian ini adalah penelitian deskriptif dengan pendekatan kuantitatif. Dari segi waktu pengumpulan data, penelitian ini berjenis penelitian cross sectional. Pengambilan sampel penelitian menggunakan teknik sampling multistage random sampling. Populasi pada penelitian ini adalah Wanita Usia Subur (WUS) yang ada di wilayah kerja Puskesmas Gurah, dan mendapatkan sampel sebanyak 98 responden.

\section{Hasil dan Pembahasan}

Berdasarkan karakteristik responden pada table 1 berikut, dapat dilihat bahwa mayoritas pendidikan terakhir responden adalah SMA/SMK dengan perolehan $62.2 \%$. Menurut umur, mayoritas responden adalah berada pada usia dewasa akhir yaitu 36-45 tahun dengan perolehan persentase 35.7\%. Pada karakteristik pekerjaan, paling banyak responden ialah IRT dengan persentase 65.3\% dari total keseluruhan responden. Sedangkan sumber keterpaparan informasi sebagian besar berasal dari media elektronik yaitu $41.8 \%$ responden. Secara lengkap, karakteristik responden dapat dilihat pada tabel berikut.

Tabel 1 Karakteristik Wanita Usia Subur (WUS)

\begin{tabular}{|l|c|c|}
\hline \multicolumn{1}{|c|}{ Variabel } & $\begin{array}{c}\text { Frekuensi } \\
\text { (n) }\end{array}$ & $\begin{array}{c}\text { Persentase } \\
\text { (\%) }\end{array}$ \\
\hline a. Pendidikan & 5 & 5.1 \\
1) SD & 29 & 29.6 \\
2) SMP & 61 & 62.2 \\
3) SMA/SMK & 3 & 3.1 \\
4) Perguruan Tinggi & & \\
\hline b. Usia & 14 & 14.3 \\
1) Remaja Awal & 17 & 17.3 \\
2) Remaja Akhir & 32 & 32.7 \\
3) Dewasa Awal & 35 & 35.7 \\
4) Dewasa Akhir & & 18.4 \\
\hline c. Pekerjaan & 18 & \\
1) Pelajar/Mahasiswa & & \\
\hline
\end{tabular}




\begin{tabular}{|l|c|c|}
\hline \multicolumn{1}{|c|}{ Variabel } & $\begin{array}{c}\text { Frekuensi } \\
\text { (n) }\end{array}$ & $\begin{array}{c}\text { Persentase } \\
\text { (\%) }\end{array}$ \\
\hline 2) IRT & 64 & 65.3 \\
3) Swasta/Wiraswasta & 14 & 14.3 \\
4) PNS & 2 & 2.0 \\
\hline d. Pekerjaan & 18 & \\
1) Pelajar/Mahasiswa & 64 & 18.4 \\
2) IRT & 14 & 65.3 \\
3) Swasta/Wiraswasta & 2 & 14.3 \\
4) PNS & 29 & 2.0 \\
\hline e. Sumber Keterpaparan & 18 & 29.6 \\
Informasi & 5 & 18.4 \\
1) Tenaga Kesehatan & 41 & 5.1 \\
2) Teman/Keluarga & 5 & 41.8 \\
3) Kader & & 5.1 \\
4) Media Elektronik & & \\
5) Media Cetak & & \\
\hline
\end{tabular}

Sumber: Data Primer, 2019.

Hasil penelitian menunjukkan bahwa pada Wanita Usia Subur (WUS) rata-rata memiliki pengetahuan yang cukup tentang HIV/AIDS dengan perolehan persentase paling tinggi yaitu $43.9 \%$ dari total keseluruhan responden, sedangkan pengetahuan mengenai penularan HIV/AIDS diperoleh hasil paling tinggi adalah pengetahuan masih rendah yaitu sebanyak 49.9\% dari keseluruhan responden. Untuk pengetahuan mengenai pencegahan diperoleh hasil sebanyak $70.4 \%$ dan 55.1\% dari seluruh total responden mengetahui tentang pencegahan. Selanjutnya, pengetahuan mengenai tanda dan gejala diperoleh hasil sebanyak $73.5 \%$ dan $59.2 \%$ dari seluruh total responden mengetahui tanda dan gejala, dan untuk persentase pengetahuan mengenai penanggulangan, diperoleh hasil sebanyak 54\% dan 53\% responden mengetahui penanggulangan.

Tabel 2. Tingkat Pengetahuan HIV/AIDS Responden

\begin{tabular}{|l|c|c|}
\hline \multicolumn{1}{|c|}{ Variabel } & (n) & (\%) \\
\hline a. Tingkat Pengetahuan HIV/AIDS & & \\
1) Sangat Rendah & 12 & 12.2 \\
2) Rendah & 34 & 34.7 \\
3) Cukup & 43 & 43.9 \\
4) Tinggi & 9 & 9.2 \\
\hline
\end{tabular}




\begin{tabular}{|c|c|c|}
\hline Variabel & (n) & (\%) \\
\hline $\begin{array}{l}\text { b. Tingkat Pengetahuan tentang cara penularan } \\
\text { HIV/AIDS } \\
\text { 1) Sangat Rendah } \\
\text { 2) Rendah } \\
\text { 3) Cukup } \\
\text { 4) Tinggi }\end{array}$ & $\begin{array}{l}20 \\
46 \\
18 \\
14\end{array}$ & $\begin{array}{l}20.4 \\
49.9 \\
18.4\end{array}$ \\
\hline $\begin{array}{l}\text { c. Pengetahuan tentang pencegahan HIV/AIDS } \\
\text { 1) Membatasi hubungan seksual } \\
\text { a) Tidak Tahu } \\
\text { b) Tahu } \\
\text { 2) Pemakaian Kondom } \\
\text { a) Tidak Tahu } \\
\text { b) Tahu }\end{array}$ & $\begin{array}{l}29 \\
69\end{array}$ & $\begin{array}{l}29.6 \\
70.4\end{array}$ \\
\hline $\begin{array}{l}\text { d. Pengetahuan tentang tanda dan gejala HIV/AIDS } \\
\text { 1) Orang Tampak Sehat } \\
\text { a) Tidak Tahu } \\
\text { b) Tahu } \\
\text { 2) Ciri terkena HIV/AIDS } \\
\text { a) Tidak Tahu } \\
\text { b) Tahu }\end{array}$ & $\begin{array}{l}26 \\
72\end{array}$ & $\begin{array}{l}26.5 \\
73.5\end{array}$ \\
\hline $\begin{array}{l}\text { e. Pengetahuan tentang penanggulangan HIV/AIDS } \\
\text { 1) Adanya Tes HIV/AIDS } \\
\text { a) Tidak Tahu } \\
\text { b) Tahu } \\
\text { 2) Tempat Pelayanan HIV/AIDS } \\
\text { a) Tidak Tahu } \\
\text { b) Tahu }\end{array}$ & $\begin{array}{l}46 \\
52\end{array}$ & $\begin{array}{l}46.9 \\
53.1\end{array}$ \\
\hline Total & 98 & 100 \\
\hline
\end{tabular}

Sumber: Data Primer, 2019

Pada tabel ketiga berikut, kami melakukan crosstab data. Tabel berikut memperlihatkan bahwa berdasarkan karakteristik pendidikan, didapatkan hasil bahwa sebagian besar Wanita Usia Subur (WUS) di Wilayah Kerja Puskesmas Gurah Kabupaten Kediri berpendidikan SMA/SMK memiliki tingkat pengetahuan yang cukup sebanyak 24 (39.9\%) responden. Berdasarkan karakteristik usia, didapatkan hasil bahwa sebagian besar yang berpengetahuan cukup, rata-rata berada pada usia dewasa awal (26 sampai 
dengan 35 tahun) yaitu sebanyak 18 (56.3\%) responden. Berdasarkan karakteristik pekerjaan, sebagian besar berprofesi sebagai Ibu Rumah Tangga (IRT) memiliki tingkat pengetahuan cukup sebanyak 29 (45.3\%) responden dan berselisih sedikit dengan yang tingkat pengetahuan rendah sebanyak 24 (37.5\%) responden. Berdasarkan karakteristik sumber keterpaparan informasi, Wanita Usia Subur (WUS) yang masih memiliki tingkat pengetahuan rendah sebagian besar memperoleh sumber informasi melalui media elektronik sebanyak 17 (41.5\%) responden.

Tabel 3 Karakteristik Wanita Usia Subur (WUS) berdasarkan Tingkat Pengetahuan HIV/AIDS

\begin{tabular}{|c|c|c|c|c|c|c|c|c|c|c|}
\hline \multirow{3}{*}{$\begin{array}{l}\text { Karakteristik } \\
\text { 1. Pendidikan }\end{array}$} & \multicolumn{10}{|c|}{ Tingkat Pengetahuan HIV/AIDS } \\
\hline & \multicolumn{2}{|c|}{$\begin{array}{l}\text { Sangat } \\
\text { Rendah }\end{array}$} & \multicolumn{2}{|c|}{ Rendah } & \multicolumn{2}{|c|}{ Cukup } & \multicolumn{2}{|c|}{ Tinggi } & \multicolumn{2}{|c|}{ Total } \\
\hline & $\mathbf{n}$ & $\%$ & $\mathbf{n}$ & $\%$ & $\mathbf{n}$ & $\%$ & $\mathbf{n}$ & $\%$ & $\mathbf{n}$ & $\%$ \\
\hline a) SD & 3 & 60 & 0 & 0 & 2 & 40 & 0 & 0 & 5 & 100 \\
\hline b) SMP & 1 & 3.4 & 12 & 41.4 & 15 & 51.7 & 1 & 3.4 & 29 & 100 \\
\hline c) SMA/SMK & 8 & 13.1 & 21 & 34.4 & 24 & 39.3 & 8 & 13.1 & 61 & 100 \\
\hline d) Perguruan Tinggi & 0 & 0 & 1 & 33.3 & 2 & 66.7 & 0 & 0 & 3 & 100 \\
\hline \multicolumn{11}{|l|}{ Usia } \\
\hline $\begin{array}{l}\text { a) Remaja Awal } \\
(12-16 \text { th. })\end{array}$ & 3 & 21.4 & 7 & 50.0 & 2 & 14.3 & 2 & 14.3 & 14 & 100 \\
\hline $\begin{array}{l}\text { b) Remaja Akhir } \\
(17-25 \text { th.) }\end{array}$ & 3 & 17.6 & 6 & 35.3 & 8 & 56.3 & 0 & 9.4 & 17 & 100 \\
\hline $\begin{array}{l}\text { c) Dewasa Awal } \\
\text { (26-35 th.) }\end{array}$ & 1 & 3.1 & 10 & 31.3 & 18 & 56.3 & 3 & 9.4 & 32 & 100 \\
\hline $\begin{array}{l}\text { d) Dewasa Akhir } \\
\text { (36-45 th.) }\end{array}$ & 5 & 14.3 & 11 & 31.4 & 15 & 42.9 & 4 & 11.4 & 35 & 100 \\
\hline \multicolumn{11}{|l|}{ Pekerjaan } \\
\hline $\begin{array}{l}\text { a) Pelajar/Mahasis } \\
\text { wa }\end{array}$ & 5 & 27.8 & 7 & 38.9 & 4 & 22.2 & 2 & 11.1 & 18 & 100 \\
\hline $\begin{array}{l}\text { b) Ibu Rumah } \\
\text { Tangga (IRT) }\end{array}$ & 5 & 7.8 & 24 & 37.5 & 29 & 45.3 & 6 & 9.4 & 64 & 100 \\
\hline $\begin{array}{l}\text { c) Swasta/Wiraswa } \\
\text { sta }\end{array}$ & 2 & 14.3 & 3 & 21.4 & 8 & 57.1 & 1 & 7.1 & 14 & 100 \\
\hline d) PNS & 0 & 0 & 0 & 0 & 2 & 100 & 0 & 0 & 2 & 100 \\
\hline \multicolumn{11}{|c|}{ Sumber Keterpaparan Informasi } \\
\hline a) Tenaga & 2 & 6.9 & 8 & 27.6 & 17 & 58.6 & 2 & 6.9 & 29 & 100 \\
\hline
\end{tabular}




\begin{tabular}{|c|l|l|l|l|l|l|l|l|l|l|}
\hline \multicolumn{1}{|c|}{ Kesehatan } & & & & & & & & & & \\
\hline b) Teman/Keluarga & 0 & 0 & 6 & 33.3 & 8 & 44.4 & 4 & 22.2 & 16 & 100 \\
\hline c) Kader & 3 & 60 & 2 & 40 & 0 & 0 & 0 & 0 & 5 & 100 \\
\hline $\begin{array}{l}\text { d) } \begin{array}{l}\text { Media } \\
\text { Elektronik }\end{array} \\
\text { e) Media Cetak }\end{array}$ & 5 & 12.2 & 17 & 41.5 & 16 & 39.0 & 3 & 7.3 & 41 & 100 \\
\hline Total & 12 & 12.2 & 34 & 34.7 & 43 & 43.9 & 9 & 9.2 & 98 & 100 \\
\hline
\end{tabular}

Sumber: Data Primer, 2019.

\section{Gambaran Karakteristik Wanita Usia Subur (WUS)}

Karakteristik responden Wanita Usia Subur (WUS) di Wilayah Kerja Puskesmas Gurah Kabupaten Kediri meliputi pendidikan, usia, pekerjaan, dan sumber keterpaparan informasi. Jumlah keseluruhan responden adalah 98 responden. Berdasarkan hasil penelitian, didapatkan bahwa mayoritas pendidikan masih berada pada jenjang SMA/SMK dengan perolehan 62.2\% dari keseluruhan responden dibandingkan dengan yang sudah berjenjang Perguruan Tinggi sangat jauh perbedaannya yaitu hanya 3 (3.1\%) dari total keseluruhan responden. Hal ini dikarenakan sebagian besar responden berprofesi sebagai Ibu Rumah Tangga (IRT) sebanyak 64 (65.3\%) dari total seluruh responden yang menghabiskan waktunya di rumah dan mengurus anaknya.

Karakteristik menurut usia, rata-rata Wanita Usia Subur (WUS) di Wilayah Puskesmas Gurah Kabupaten Kediri berada pada usia dewasa awal dan akhir (26-45 tahun) dengan perolehan persentase berselisih sedikit yaitu 32 (32.7\%) dan 35 (35.7\%) dari seluruh responden. Hal ini dikarenakan sebagian besar responden yang sudah berprofesi sebagai Ibu Rumah Tangga (IRT) dan sudah memiliki anak sehingga berada pada rata-rata usia dewasa. Sedangkan untuk karakteristik mengenai sumber keterpaparan informasi HIV/AIDS pada responden Wanita Usia Subur (WUS) diperoleh hasil bahwa sebagian besar responden mengetahui informasi mengenai HIV/AIDS melalui media elektronik dengan perolehan persentase sebesar $41.8 \%$ dari keseluruhan responden. Hal ini dikarenakan media elektronik yang mudah di akses dimana saja dan kapan saja serta mudah dijangkau segala usia termasuk yang berprofesi sebagai Ibu Rumah Tangga (IRT).

\section{Tingkat Pengetahuan HIV/AIDS Responden}

Tingkat pengetahuan Wanita Usia Subur (WUS) di Wilayah Puskesmas Gurah Kabupaten Kediri sebagian besar sudah berpengetahuan cukup sebanyak 43.9\% dari seluruh total responden. Namun responden yang masih berpengetahuan rendah juga masih cukup banyak yaitu memperoleh peresentase 34.7\%, sedangkan responden yang 
berpengetahuan tinggi masih sangat sedikit sebanyak 9.2\%. Pengetahuan adalah hasil dari "Tahu" yang terjadi setelah orang melakukan pengindraan terhadap suatu objek tertentu. Pengindraan terjadi melalui pancaindra manusia, yaitu indra penglihatan, pendengaran, penciuman, rasa, dan raba. ${ }^{11}$

Hal ini dikarenakan sebagian besar responden mengetahui informasi mengenai HIV/AIDS melalui media elektronik serta kurangnya mengenai sosialisasi atau penyuluhan yang dilakukan di lingkungan responden. Hal tersebut juga dikarenakan sebagian besar responden berprofesi sebagai Ibu Rumah Tangga, sehingga akses untuk mendapatkan informasi hanya sebatas di lingkungan sekitar dan melalui media elektronik yang dapat diakses di dalam rumah. Penelitian ini sejalan dengan penelitian dari Wardani pada tahun 2017 yang menyebutkan mengenai sebagian besar responden memiliki tingkat pengetahuan yang cukup dikarenakan belum pernah mendapatkan informasi kesehatan mengenai HIV/AIDS seperti penyuluhan tentang HIV/AIDS sebelumnya. ${ }^{12}$

Dari pernyataan yang menyebutkan masih rendahnya pengetahuan mengenai HIV/AIDS pada Wanita Usia Subur (WUS) maka akan berdampak pada semakin meningkatnya angka kejadian HIV/AIDS khususnya di kalangan Wanita Usia Subur (WUS). Hal ini didukung oleh pendapat dari Dalimoenthe yang menyebutkan bahwa HIV/AIDS tidak hanya mengancam kelompok dengan perilaku seks risiko tinggi, tetapi juga mengancam kalangan IRT. Hal ini dikarenakan kurangnya akses informasi dan pendidikan perempuan sehingga tidak memiliki pengetahuan cukup mengenai HIV/AIDS. ${ }^{13}$

\section{Tingkat Pengetahuan tentang Cara Penularan}

Hasil penelitian menunjukkan bahwa tingkat pengetahuan tentang cara penularan HIV/AIDS pada responden Wanita Usia Subur (WUS) masih rendah, yaitu mendapatkan persentase sebesar $49.9 \%$ dari seluruh jumlah responden atau hampir setengah total responden masih memiliki tingkat pengetahuan mengenai cara penularan yang rendah. Ditinjau dari beberapa pertanyaan seperti pemakaian kondom, banyak yang menyebutkan bahwa kondom belum dapat mengurangi risiko terkena HIV/AIDS atau masih beranggapan bahwa meskipun memakai kondom, masih dapat menyebabkan terjadinya infeksi HIV/AIDS. Sebagian responden juga masih menganggap bahwa makan sepiring dengan orang yang terinfeksi HIV/AIDS (ODHA) dapat menyebabkan seseorang

11 Ibid.

12 Ibid.

13 Ikhlasiah Dalimoenthe, "Perempuan Dalam Cengkeraman HIV/AIDS: Kajian Sosiologi Feminis Perempuan Ibu Rumah Tangga," Jurnal Komunitas 5, no. 1 (2011): 41-48. 
tertular HIV/AIDS. Sejumlah responden juga percaya bahwa HIV dapat ditularkan melalui gigitan nyamuk, dan melalui air liur penderita HIV/AIDS.

Nyatanya, HIV/AIDS dapat ditularkan melalui 3 cara yaitu 1) melalui hubungan seksual tanpa kondom (vagina atau anal) termasuk jika melakukan seks oral dengan orang yang terinfeksi; 2) transfusi darah yang terkontaminasi, jarum suntik, peralatan bedah atau instrument tajam lainnya yang terkontaminasi, dan 3) melalui ibu pada bayinya selama proses kehamilan, persalinan dan menyusui. ${ }^{14}$

Hasil penelitian ini sejalan dengan penelitian Wardani (2017) yang mengemukakan bahwa sebagian besar responden masih kurang mengerti tentang cara penularan HIV/AIDS dan beranggapan bahwa satu rumah dengan penderita dapat menularkan penyakit tersebut. Dampak jika Wanita Usia Subur (WUS) tidak memiliki pengetahuan cara penularan yang baik maka akan berisiko terjadi penularan vertikal yaitu penularan dari ibu kepada bayi pada saat masa kehamilan, ketika melahirkan, ataupun menyusui, sehingga dapat melahirkan bayi dengan positif terinfeksi.

\section{Pengetahuan tentang Pencegahan HIV/AIDS}

Dari hasil penelitian dengan 98 responden, menunjukkan bahwa 69 dari 98 responden menjawab dengan benar pertanyaan mengenai pembatasan hubungan seksual (tidak gonta-ganti pasangan) dapat mencegah terjadinya infeksi HIV/AIDS. Hal ini sesuai dengan teori Nugroho yang menyebutkan bahwa pencegahan HIV/AIDS dapat dilakukan dengan setia terhadap satu pasangan saja dan tidak melakukan hubungan seksual yang berisiko. ${ }^{15}$ Sedangkan pertanyaan lain mengenai pencegahan dengan memakai kondom pada saat melakukan hubungan seksual memperoleh hasil yang hampir seimbang antara jawaban benar dan salah, responden menjawab benar yaitu 54 (55.1\%) dari 98 responden dan responden menjawab salah yaitu 44 (44.9\%) dari 98 responden. Hal ini dikarenakan sebagian besar responden masih beranggapan bahwa dengan memakai kondom tetap akan berisiko terinfeksi virus HIV/AIDS. Teori mengenai pencegahan juga menyebutkan bahwa penggunaan kondom dapat mencegah masuknya virus HIV/AIDS melalui cairan sperma orang yang terinfeksi HIV/AIDS. 16

Hasil analisis ini didukung penelitian yang berpendapat bahwa pengetahuan terhadap pencegahan HIV mendorong seseorang untuk memberikan perlindungan terhadap diri sendiri dengan maksimal, namun dengan kurangnya pengetahuan terhadap pencegahan akan dapat menyebabkan seseorang menjadi tidak peduli

14 World Health Organization, Consolidated Guideline on Sexual and Reproductive Health and Rights of Women Living with HIV.

15 Chasy Meilana, "Tingkat Pengetahuan Remaja Tentang HIV/AIDS Pada Siswa Kelas XI Di SMA Al Islam I Surakarta” (STIKES Kusuma Husada Surakarta, 2015).

16 Ibid. 
terhadap perlindungan diri. ${ }^{17}$ Termasuk dengan Wanita Usia Subur (WUS) yang jika tidak mengetahui bagaimana cara pencegahan yang baik terhadap infeksi HIV/AIDS akan berdampak pada perilaku seksual yang berisiko seperti seks bebas tanpa menggunakan alat pengaman (kondom) sehingga menyebabkan terjadinya penularan infeksi HIV/AIDS melalui cairan sperma dari kelompok berisiko.

\section{Pengetahuan tentang Tanda dan Gejala HIV/AIDS}

Berdasarkan hasil penelitian, sebagian besar responden menjawab ya pada pertanyaan mengenai mungkinkah seseorang dengan penampilan tampak sehat ternyata ia telah tertular virus HIV/AIDS yaitu sebanyak 72 (73.5\%) dari 98 responden. Hal ini sejalan dengan penelitian Wardani (2017) yang berpendapat bahwa orang yang hidup dengan HIV/AIDS umumnya tidak menyadari tentang status HIV/AIDS mereka tanpa tes karena mereka terlihat sehat. Pertanyaan lainnya, yaitu mengenai cara mengetahui seseorang terinfeksi virus HIV/AIDS, mendapat skor hampir sama antara yang menjawab benar dan salah, menjawab benar yaitu sebanyak 58 (59.2\%) dari 98 responden sedangkan menjawab salah yaitu sebanyak 40 (40.8\%) dari 98 responden. Sebagian besar responden tahu bahwa untuk mengetahui seseorang terinfeksi maka perlu dilakukan tes darah, ada beberapa yang menjawab dengan mengenali fisik, maupun mengenali perilaku penderita. Dan sebagian lagi menjawab tidak tahu bagaimana cara mengetahui seseorang terinfeksi HIV/AIDS.

Pada beberapa orang yang terinfeksi HIV, ditemukan adanya flu demam, sakit kepala, kelelahan, dan ruam-ruam merah. Untuk penderita lainnya mungkin tidak ditemukan gejala. Itulah sebabnya, jika berisiko terkena virus ini maka jalan satusatunya adalah melakukan pemeriksaan HIV untuk mengetahui apakah orang tersebut terinfeksi HIV. Orang dengan HIV dapat saja merasa baik dan terlihat sehat. Oleh karena itu infeksi ini jadi jarang disadari. ${ }^{18}$

Kurangnya pengetahuan mengenai tanda dan gejala akan berdampak pada sikap perempuan yang pasrah dengan keadaan jika sudah terjangkit virus HIV/AIDS dimana banyaknya kasus perempuan yang terinfeksi dari suami atau pacar mereka yang berawal dari ketidaktahuan atas status HIV positif pasangannya. Selain itu juga karena rendahnya daya tawar atau negoisasi dalam berhubungan seksual. ${ }^{19}$

\section{Pengetahuan tentang Penanggulangan HIV/AIDS}

17 Faritz Aldi Ramanda, “Gambaran Tingkat Pengetahuan Perawat Terhadap HIV” (Universitas Indonesia, 2014).

18 Ibid.

19 Dalimoenthe, "Perempuan Dalam Cengkeraman HIV/AIDS: Kajian Sosiologi Feminis Perempuan Ibu Rumah Tangga."

Copyright $($ 2020; MASOKAN, ISSN: $\quad$ (print), $\quad$ (online) | 22 
Dari hasil penelitian, didapatkan bahwa frekuensi antara menjawab benar dan salah hampir sama, dimana jumlah responden menjawab benar yaitu sebanyak 53 (54.1\%) dari 98 responden, sedangkan menjawab salah yaitu sebanyak 45 (45.9\%) dari 98 responden pada pertanyaan tahukah mereka tentang adanya tes HIV. Sebagian besar responden yang menjawab tahu tentang adanya tes HIV adalah responden yang dapat menjawab mengenai cara mengenali seseorang terinfeksi dengan melakukan tes darah, tetapi tidak mengetahui nama tes HIV/AIDS. Sedangkan pada pertanyaan mengenai tempat pelayanan tes HIV, sebagian besar responden menjawab mengetahui tentang tempat pelayanan tes HIV/AIDS sebanyak 52 dari 98 responden, dan menjawab tidak tahu sebanyak 46 dari 98 responden. Mayoritas responden mengetahui tempat pelayanan HIV/AIDS yaitu rumah sakit, dan pergi ke dokter. Selain itu ada beberapa responden yang sudah mengetahui bahwa di puskesmas tersedia layanan tes HIV/AIDS karena sudah pernah melakukan tes tersebut pada saat kehamilan.

Peraturan Menteri Kesehatan Nomor 21 Tahun 2013 mengenai penanggulangan HIV dan AIDS juga ditegaskan bahwa tes HIV perlu dilakukan untuk orang-orang dengan indikasi sebagai berikut: 1) orang dewasa, anak, dan remaja dengan kondisi diduga terjadi infeksi HIV terutama pasien riwayat TB dan IMS; 2) asuhan antenatal pada ibu hamil dan ibu bersalin; 3) laki-laki dewasa yang meminta sirkumisisi sebagai tindakan pencegahan HIV. ${ }^{20}$

Rendahnya pengetahuan mengenai layanan VCT akan berdampak pada ketidaktahuan mengenai HIV/AIDS yang mungkin sudah terjangkit ditubuh penderita, sehingga jika tidak segera dilakukan diagnosa dapat mempersulit pengobatan menggunakan ARV dan jika terjadi kehamilan dapat menularkan ke bayinya pada saat proses melahirkan maupun saat menyusui.

\section{Karakteristik Wanita Usia Subur (WUS) Berdasarkan Tingkat Pengetahuan HIV/AIDS}

\section{Karakteristik Pendidikan Berdasarkan Tingkat Pengetahuan HIV/AIDS}

Berdasarkan hasil penelitian menunjukkan bahwa tingkat pengetahuan Wanita Usia Subur (WUS) yang memiliki tingkatan cukup sebanyak 39.3\% dari 61 responden yang berpendidikan SMA/SMK. Pendidikan adalah sebuah usaha untuk mengembangkan kepribadian dan kemampuan di dalam dan di luar sekolah dan berlangsung seumur

20 KEMENTERIAN KESEHATAN REPUBLIK INDONESIA, Peraturan Menteri Kesehatan Tentang Penanggulangan HIV Dan AIDS (Indonesia, 2013). 
hidup. Semakin tinggi pendidikan seseorang maka semakin mudah seseorang dalam menerima informasi. ${ }^{21}$

Pada penelitian Septiara, disebutkan bahwa orang yang berlatar belakang pendidikan SMA/SMK saja memiliki tingkat pengetahuan yang cukup pada berbagai hal. Pengetahuan sendiri, erat hubungannya dengan pendidikan sehingga diharapkan dengan adanya pendidikan tinggi maka seseorang akan semakin luas pengetahuannya. ${ }^{13}$ Hal ini sejalan dengan penelitian Mwamwenda tentang HIV/AIDS yang menyebutkan bahwa ada hubungan antara tingkat pendidikan dengan pengetahuan tentang HIV/AIDS, dimana semakin tinggi tingkat pendidikan seseorang maka semakin baik pengetahuannya tentang HIV/AIDS.

\section{Karakteristik Usia Berdasarkan Tingkat Pengetahuan HIV/AIDS}

Berdasarkan hasil penelitian menunjukkan bahwa tingkat pengetahuan Wanita Usia Subur (WUS) yang cukup mayoritas berada pada fase dewasa awal dan dewasa akhir berusia diatas 26 tahun sampai dengan 45 tahun sebanyak 18 (56.3\%) responden dari total responden Wanita Usia Subur (WUS). Usia atau umur seseorang berhubungan dengan daya tangkap dan pola pikirnya. Semakin bertambah usia maka akan semakin berkembang pola daya tangkap dan pola pikir sehingga pengetahuan yang diperoleh semakin baik. Namun untuk IQ, akan menurun sejalan dengan bertambahnya usia. ${ }^{22}$

\section{Karakteristik Pekerjaan berdasarkan Tingkat Pengetahuan HIV/AIDS}

Berdasarkan hasil penelitian, tingkat pengetahuan cukup Wanita Usia Subur sebagian besar berprofesi sebagai Ibu Rumah Tangga dengan perolehan persentase sebanyak 29 (45.3\%) dan berselisih sedikit dengan tingkat pengetahuannya yang masih rendah yaitu sebanyak 24 (37.5\%) dari total keseluruhan responden. Pekerjaan adalah faktor yang mempengaruhi pengetahuan ditinjau dari jenis pekerjaan yang sering berinteraksi dengan orang lain akan lebih banyak pengetahuannya dibandingkan dengan orang yang bekerja tanpa ada interaksi dengan orang lain.

Pengalaman belajar saat bekerja yang dikembangkan dapat memberikan pengetahuan dan keterampilan profesional pada seseorang dan dapat mengembangkan kemampuan mengambil keputusan orang tersebut. ${ }^{23}$

Hal tersebut sesuai dengan teori Notoatmodjo dalam Septiara, yang mengemukakan pendapat terkait dengan informasi, seseorang yang mempunyai

${ }^{21}$ Amalia Pasanda, "Perbedaan Pengetahuan, Sikap Dan Perilaku Penjamah Makanan Sesudah Diberikan Penyuluhan Personal Hygiene Di Hotel Patra Jasa Semarang" (Universitas Muhammadiah Semarang, 2016).

22 Ibid.

${ }^{23}$ Ibid. 
informasi lebih banyak akan mempunyai pengetahuan luas dan dikaitkan dengan pekerjaan responden dalam penelitian ini yaitu sebagian besar tidak bekerja karena merupakan Ibu Rumah Tangga yang dapat diasumsikan masih kurang mendapatkan informasi mengenai HIV/AIDS ini. Namun dengan adanya kegiatan Posyandu maka dapat diatasi dengan informasi yang diberikan oleh petugas kesehatan. ${ }^{24}$

\section{Sumber Keterpaparan Informasi berdasarkan Tingkat Pengetahuan HIV/AIDS}

Berdasarkan hasil penelitian dengan 98 responden, dari 5 kategori sumber informasi yaitu tenaga kesehatan, teman/keluarga, kader, media elektronik, dan media cetak, terdapat 17 (41.5\%) responden yang masih memiliki tingkat pengetahuan rendah memperoleh informasi mengenai HIV/AIDS melalui media elektronik seperti televisi, radio, handphone, dan lain sebagainya. Hal tersebut dikarenakan sebagian besar responden berprofesi sebagai Ibu Rumah Tangga yang lebih banyak menghabiskan waktunya di dalam rumah, sehingga banyak dari mereka memperoleh informasi hanya melalui media elektronik. Media elektronik sendiri merupakan suatu hasil dari kemajuan teknologi dimana informasi yang dapat dicari dengan cepat dan mudah, sehingga tingkat pengetahuannya adalah cukup.

Penelitian ini sejalan dengan penelitian yang menyebutkan bahwa tingkat pengetahuan cukup mengenai HIV/AIDS adalah responden yang mengatakan sedikit mengetahui informasi dari berbagai sumber seperti lingkungan dan elektronik meskipun belum jelas, walaupun beberapa penelitian mengungkapkan bahwa pengetahuan tentang HIV/AIDS sudah baik dimana sebagian besar telah mendapatkan informasi melalui surat kabar, radio, leaflet, dan penyuluhan tentang HIV. ${ }^{25}$

\section{Kesimpulan}

Mayoritas responden berpendidikan terakhir pada jenjang SMA/SMK, sedangkan usia mayoritas responden berada pada usia dewasa akhir yaitu antara usia 36-45 tahun namun berselisih sedikit dengan usia dewasa awal yaitu antara usia 26-35 tahun. Untuk pekerjaan hampir dari seluruh responden berprofesi sebagai Ibu Rumah Tangga (IRT). Dan untuk sumber keterpaparan informasi terkait HIV/AIDS paling banyak adalah melalui media elektronik seperti televisi, handphone, dan lain-lain.

Tingkat pengetahuan HIV/AIDS pada Wanita Usia Subur (WUS) di wilayah Puskesmas Gurah sebagian besar memiliki pengetahuan yang cukup dan berselisih

\footnotetext{
${ }^{24}$ Dwi Septiara, Mufdilah, and Luluk Rosida, "GAMBARAN TINGKAT PENGETAHUAN DAN SIKAP IBU HAMIL YANG MEMANFAATKAN PITC TERHADAP PENYAKIT HIV/AIDS DI PUSKESMAS KRETEK KABUPATEN BANTUL YOGYAKARTA.” (UNISA Yogyakarta, 2017).

${ }^{25}$ Tri Ayu Lestari, "Gambaran Tingkat Pengetahuan Ibu Rumah Tangga Tentang Penularan Dan Pencegahan HIV/AIDS Di RT 01 Dusun Dagaran Desa Palbapang Bantul" (Universitas Muhammadiyah Yogyakarta, 2017).
} 
sedikit dengan yang berpengetahuan rendah namun hanya sedikit yang berpengetahuan tinggi. Sedangkan tingkat pengetahuan mengenai cara penularan HIV/AIDS mayoritas masih rendah, untuk pengetahuan mengenai pencegahan sebagian besar responden sudah mengetahui pencegahan dengan membatasi hubungan seksual sedangkan pengetahuan mengenai pencegahan dengan pemakaian kondom sebagian orang mengetahui dan sebagian lainnya tidak mengetahui. Untuk pengetahuan tentang tanda dan gejala mayoritas responden mengetahui orang yang tampak sehat memungkinkan terkena HIV/AIDS, dan sebagian orang mengetahui ciri dari orang yang terkena HIV/AIDS namun sebagian lagi tidak mengetahuinya. Selanjutnya untuk pengetahuan mengenai penanggulangan, sebagian orang mengetahui adanya tes HIV/AIDS dan tempat pelayanan yang disediakan tes HIV/AIDS, namun sebagian lainnya tidak mengetahui.

Karakteristik Wanita Usia Subur (WUS) berdasarkan tingkat pengetahuan HIV/AIDS meliputi pendidikan adalah yang memiliki tingkat cukup sebagian besar berpendidikan terakhir pada jenjang SMA/SMK, sedangkan karakteristik usia yang memiliki tingkat cukup berada pada rata-rata usia dewasa awal dan akhir (26-45 th), untuk karakteristik pekerjaan, yang memiliki tingkat pengetahuan cukup sebagian besar berprofesi sebagai Ibu Rumah Tangga (IRT) dan untuk sumber keterpaparan informasi, mayoritas memiliki tingkat pengetahuan rendah yang mendapatkan informasi melalui media elektronik. Kami menyarankan agar Puskesmas dan tenaga kesehatan yang bertugas di setiap wilayah desa binaan dapat memberikan pelayanan kesehatan yang lebih optimal, teruma program yang bersifat preventif atau pencegahan primer melalui promosi kesehatan tentang HIV/AIDS meliputi cara penularan, pencegahan serta mengenai manfaat pelayanan VCT yang sudah tersedia di Puskesmas untuk menekan dan memutuskan rantai penularan HIV/AIDS di masyarakat terutama pada Wanita Usia Subur yang berusia antara 26-45 tahun.

\section{Referensi}

Dalimoenthe, Ikhlasiah. "Perempuan Dalam Cengkeraman HIV/AIDS: Kajian Sosiologi Feminis Perempuan Ibu Rumah Tangga." Jurnal Komunitas 5, no. 1 (2011): 41-48.

Direktorat Jenderal Penanggulangan dan Pencegahan Penyakit serta Penyehatan Lingkungan, Kemenkes. Laporan Perkembangan HIV-AIDS \& Penyakit Infeksi Menular Seksual (PIMS) Triwulan I Tahun 2017., 2017.

Indriastuti, Nur Azizah. "Faktor-Faktor Yang Mempengaruhi Pencapaian Peran Sebagai Ibu Pada Perempuan Dengan HIV/AIDS Di Yogyakarta." Mutiara Medika: Jurnal Kedokteran dan Kesehatan 15, no. 1 (2015): 75-83.

KEMENKES. Profil Kesehatan Indonesia Tahun 2016, 2016. 
KEMENTERIAN KESEHATAN REPUBLIK INDONESIA. Peraturan Menteri Kesehatan Tentang Penanggulangan HIV Dan AIDS. Indonesia, 2013.

-_- Profil Kesehatan Indonesia Tahun 2017. JAKARTA, 2017.

_-_. "Profile Kesehatan Indonesia Tahun 2017." Ministry of Health Indonesia.

Lestari, Tri Ayu. "Gambaran Tingkat Pengetahuan Ibu Rumah Tangga Tentang Penularan Dan Pencegahan HIV/AIDS Di RT 01 Dusun Dagaran Desa Palbapang Bantul." Universitas Muhammadiyah Yogyakarta, 2017.

Meilana, Chasy. “Tingkat Pengetahuan Remaja Tentang HIV/AIDS Pada Siswa Kelas XI Di SMA Al Islam I Surakarta." STIKES Kusuma Husada Surakarta, 2015.

Pasanda, Amalia. "Perbedaan Pengetahuan, Sikap Dan Perilaku Penjamah Makanan Sesudah Diberikan Penyuluhan Personal Hygiene Di Hotel Patra Jasa Semarang." Universitas Muhammadiah Semarang, 2016.

Ramanda, Faritz Aldi. "Gambaran Tingkat Pengetahuan Perawat Terhadap HIV." Universitas Indonesia, 2014.

Septiara, Dwi, Mufdilah, and Luluk Rosida. “GAMBARAN TINGKAT PENGETAHUAN DAN SIKAP IBU HAMIL YANG MEMANFAATKAN PITC TERHADAP PENYAKIT HIV/AIDS DI PUSKESMAS KRETEK KABUPATEN BANTUL YOGYAKARTA." UNISA Yogyakarta, 2017.

World Health Organization. Consolidated Guideline on Sexual and Reproductive Health and Rights of Women Living with HIV, 2017.

_-_. Global Update on HIV Treatment 2013: Results, Impact and Opportunities, 2013. 